Mineralogical Journal, Vol. 2, No. 6, PP. 408-421, Aug., 1959

\title{
THE MINERALS OF THE NODA-TAMAGAWA MINE, IWATE PREFECTURE, JAPAN
}

\author{
I. Notes on Geology and Parageneses of Minerals
}

\author{
TAKEO WATANABE \\ Geological Institute, University of Tokyo
}

\begin{abstract}
The ore deposits of the Noda-Tamagawa mine have become famous for their wealth of mineral species, the production of high grade manganese ores, and also the recent discovery of uranium ores. More than seventy minerals have been found in this mining area including such rare minerals as pyrochroite, manganosite, vredenburgite, yoshimuraite (a new mineral of $\mathrm{Ba}, \mathrm{Sr}, \mathrm{Mn}, \mathrm{Ti}$-silicate), etc.

The ore deposits of this mine may be classified into the following types:

(A) The contact-metamorphosed bedded manganese deposits in meta. morphosed roof pendant in the batholithic mass of granitic rocks.

(B) (1) The uranium-bearing veins.

(2) The cobalt-nickel-molybdenum-bearing uranium deposits associated with pelitic hornfels.

(C) Pyrometasomatic copper-bearing pyrrhotite deposits found in limestone.

(D) Gold-silver-bearing quartz-arsenopyrite veins.

Among them manganese deposits are economically the most important ones. The geology and ore deposits of the mine are briefly described. The mineral parageneses of ores and country rocks are shown in Tables 1 and 2.
\end{abstract}

\section{Introduction}

The Noda-Tamagawa mine, one of the important manganese producers in Japan, is located about $16 \mathrm{~km}$. south-east of Kuji City, in the north-eastern part of Iwaté Prefecture (Fig. 1).

The mine had been almost unknown before the discovery of a rich primary manganese ore-body below the oxidized zone in 1948 . Not far from this manganese ore zone lies the copper-bearing pyr- 
rhotite deposit which was once exploited for copper in 1919. In order to know the genetic relation between the manganese deposits and the cupriferous pyrrhotite deposits the author, together with his student Mr. S. Yui, began to study the geology of this mining district. In the course of his study the author discovered abundant occurrences of manganese minerals which have hitherto been known as rare minerals. More than fifty thousand tons of the pyrochroitemanganosite ore has been shipped to the smelter for metallurgical uses. Various kinds of manganese silicate minerals have also been found. The paragenesis of minerals of the deposits is very complex and resembles in some degrees those of Kaso, Långban and Franklin.

Furthermore, the new occurrence of uranium minerals has recently been recorded.

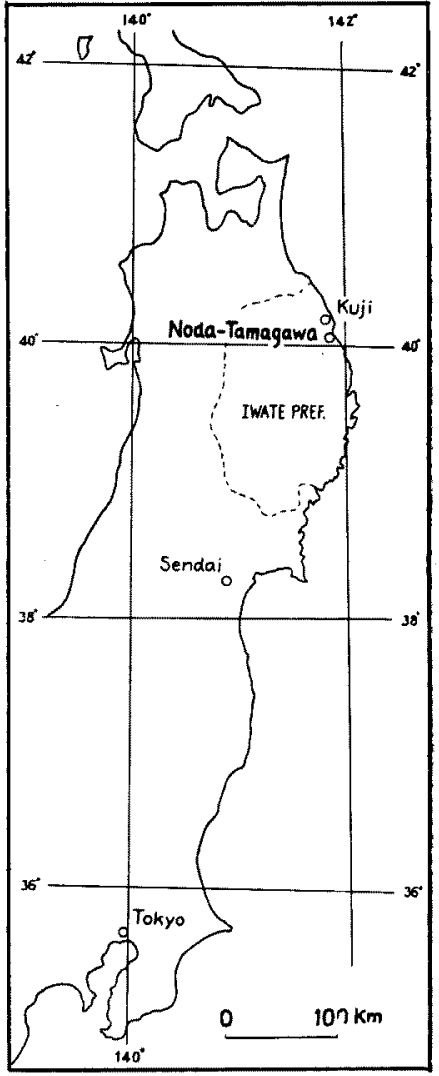

Fig. 1. Index map showing the location of the NodaTamagawa Mine.

In this paper the author wishes to present a brief explanation of the occurrences of minerals, geo$\operatorname{logic}$ setting, and his hypothesis of the origin of the deposits.

Detailed description of the minerals of this remarkable mining district will be given in future papers.

\section{Previous Works}

The Noda-Tamagawa mine had not been known as a mineral locality before $\mathrm{K}$. Kawai ${ }^{3)}$ reported in 1933 the occurrence of 
410. The Minerals of the Noda-Tamagawa Mine, Iwate Prefecture penwithite, a neotocite-like mineral, associated with manganese ores of this mine.

Later the mine was visited by $T$. Yoshimura ${ }^{17}$ ) and he found some interesting manganese minerals among which picrourbanite and riebeckrichterite were discovered and described in 1937. The optical properties and chemical composition of these minerals were given in his book "The manganese deposits of Japan" ${ }^{18)}$ published in 1952.

In the course of his geochemical study of the manganese deposits of Japan, J. Kitahara ${ }^{4)^{5)}}$ studied the manganese deposits and later recorded the occurrence of the crystals of arsenopyrite from the quartz vein in 1940.

A brief description of the geology of the Noda-Tamagawa manganese mine was given by $M$. Doi ${ }^{1)}$ just after the discovery of the rich part of the Misago ore body in 1949.

In 1951 the author and S. Yui began to study the geology and ore deposits of the Noda-Tamagawa mine, and the next year, the outline of geology and mineral paragenesis are described by Yui in his graduation thesis presented to the University of Tokyo.

Genesis and contact-metamorphism of the manganese deposits were discussed by the author ${ }^{15}$ ) in 1953. He concluded that the deposits were originally of exhalative-sedimentary type and later contact-metamorphosed due to the granitic intrusion.

In his comprehensive work on manganese minerals of Japan D. E. Lee $\left.{ }^{6}\right)$ recorded the occurrence of hausmannite, pyrophanite, picrotephroite, rhodonite, neotocite, bementite, etc. in the NodaTamagawa mine. The result of a chemical analysis of the picrotephroite is given in this paper.

In $1952 \mathrm{H}$. Miyamoto ${ }^{7}$, Y. Ishida and other members of the Geological Survey of Japan carried out geological and geochemical survey of this mining area and published their paper.

During the extensive prospecting for uranium ores in the Kitakami Mountain district, a new occurrence of uranium-bearing ores 
was announced by $\mathrm{Y}$. Okumi ${ }^{8}$ ) et al., geologists of the Geological Survey of Japan, in 1957. Since then, detailed underground survey has been carried out by geologists of the mine and the Geological Survey of Japan. The paragenesis of uranium ores was first described by T. Hamaji ${ }^{2}$ and Y. Sakamaki, geologists of the Geological Survey of Japan, in 1957.

T. Takeuchi ${ }^{12)}$ and M. Nambu engaged in microscopic investigation of copper-bearing pyrrhotite ore of the Shinmaida ore body and they found cubanite in 1953. This deposit was again surveyed by A. Sugaki ${ }^{11)}$ and $\mathrm{H}$. Abe in 1957. An analysis of hausmannite in the rich manganese ore was given by $\mathrm{K}$. Omori $\mathrm{i}^{9)}$ and $\mathrm{S}$. Hasegawa in 1955.

An excellent geologic account of the Noda-Tamagawa manganese deposits was given by A. Sato ${ }^{10}, \mathrm{~K}$. Fukuda and T. Wada, geologists of the Shinkohatsu Mining Company in 1957.

Since 1951 the author has frequently visited the mine and there have been many additions to the list of minerals of Noda-Tamagawa.

\section{Outline of Geology and Ore Deposits}

\section{(a) Geology}

The rocks in the mining district consist mainly of slate, sandstone, thin-bedded chert, massive chert and limestone of unknown age. Lithologically, they resemble the rocks of the Palaeozoic (Chichibu) formation extensively developed in the northern part of the Kitakami Mountainland. These rocks have been strongly folded and compressed, and they have been intruded and thermally metamorphosed by the granitic magmas of probable Cretaceous age. Therefore, the rocks may be described as slaty hornfels, arenaceous hornfels, thin-bedded meta-chert, massive quartzite and crystalline limestone.

In the northeastern part of the district, these older rocks are covered unconformably by the upper Cretaceous beds belonging to 
412 The Minerals of the Noda-Tamagawa Mine, Iwaté Prefecture

the Kuji formation and the Tertiary beds of the Noda formation. Moreover, the Quaternary terrace deposits cover extensively all the formations above mentioned.

Due to the severe deformation the older formation stands in steeply inclined beds and is tightly folded in many places. The prevailing strike is northwest, but $\mathrm{N} .10^{\circ} \sim 20^{\circ} \mathrm{W}$. in the eastern

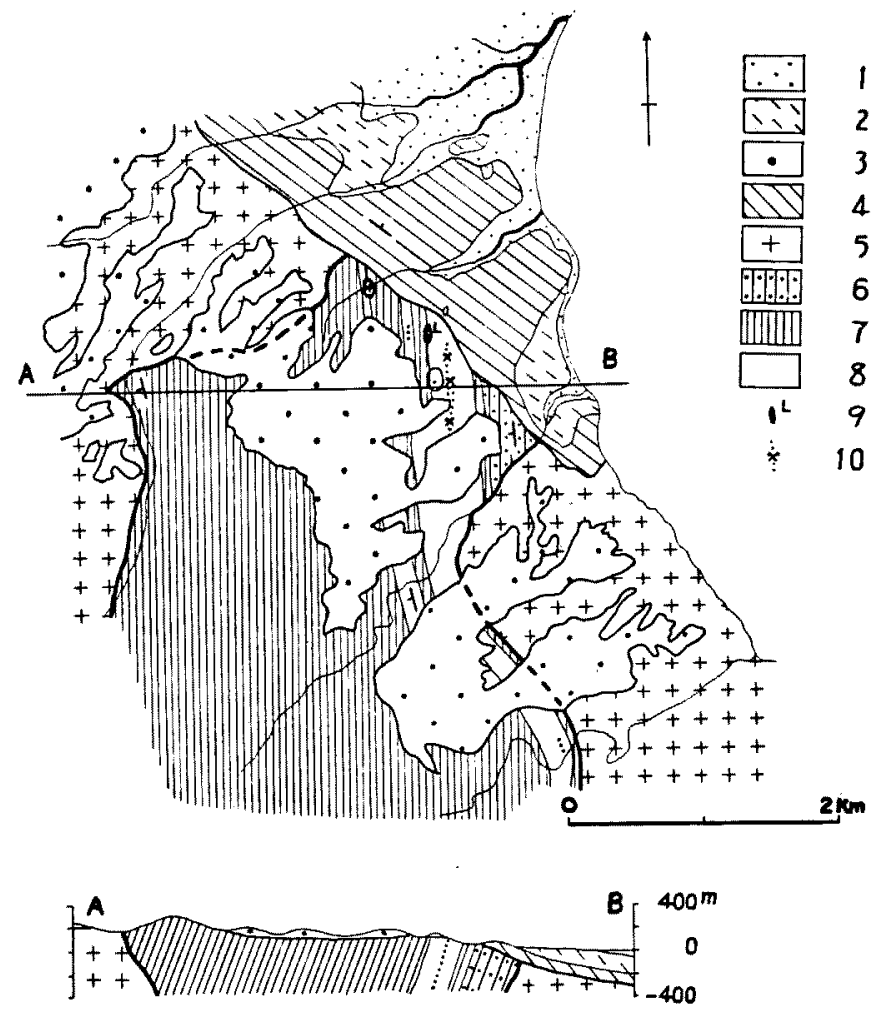

Fig. 2. Geological map and section of the Noda-Tamagawa mining area. (After Yui and Fukuda)

1. Alluvial formation. 2. Lower terrace deposits. 3. Higher terrace deposits. 4. Kuji Mesozoic formation. 5. Akka granite (granodiorite). 6. Sandstone-hornfels. 7. Pelitic hornfels. 8. Siliceous hornfels of chert origin. 9. Limestone (Shinmaida copper-bearing pyrrhotite deposit of pyrometasomatic type). 10. Manganese ore zone. 
part. The dip is generally $60^{\circ} \sim 85^{\circ}$ west.

The country rocks of the manganese deposits consist of highly thermal-metamorphosed meta-cherts including massive and thinbedded quartzite and biotite hornfels. They strike generally N. $10^{\circ}$ $\sim 20^{\circ} \mathrm{E}$. and dip nearly vertically. Generally the structure is very simple but locally it is very complex, the country rocks together with ore bodies having been strongly folded into sharp syncline or anticline plunging about $45^{\circ}$ to the southwest. The linear structure, due to the crinkle of the rocks and minor foldings, is generally parallel to the major fold axis. The geological sketch map is shown in Fig. 2.

\section{(b) Ore deposits}

The ore deposits of the Noda-Tamagawa mine may be classified tentatively into the following types:

(A) Manganese deposits.

(B) Uranium deposits.

(1) Vein type.

(2) Hornfels type.

(C) Copper-bearing pyrrhotite deposit of pyrometasomatic type.

(D) Gold-silver-bearing arsenopyrite-quartz-carbonate veins. Economically the manganese deposits are the most important.

\section{(A) Manganese deposits}

The manganese deposits in the mining area are found exclusively in meta-cherts. They are of bedded type and have been thermally metamorphosed into complex ores. Three ore zones have hitherto been known and named respectively, the Shinmaida, Misago and Kamishiro ore zones among which the second is the most productive and important.

The distribution of chert suggests that the Maida, Takada, Misago and Kirihata ore bodies are at essentially the same stratigraphic horizon called the Misago ore-zone. This zone can be traced about $1,200 \mathrm{~m}$. along the strike on the surface and is known 


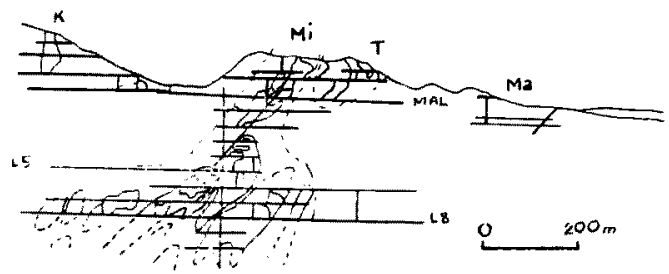

Fig. 3. Longitudinal section of the Misago manganese ore zone of the Noda-Tamagawa mine.

K: Kirihata, Mi : Misago, T: Takada and Ma: Maida ore bodies.

to be more than $300 \mathrm{~m}$. in depth. The manganese ores form lenticular beds between thin-bedded meta-chert and massive quartzite. The ore bodies range in length from one meter to two hundred meters along the strike and are usually elongated along the lineation of the country rocks or along the plunging axis of the folds. The ratio of the longest diameter of each ore body to the shortest along the bedding plane is more than three. Thickness of the mined ore bodies ranges from a half to three meters.

The manganese ores in this mine may be roughly divided into the following types according to their mineral content:

(1) Pyrochroite ore (Kimiman- or Kibiman-kô).

(2) Manganese carbonate ore (Tanman-kô).

(3) Hausmannite ore (Tetsuman-kô).

(4) Braunite ore.

(5) Tephroite ore (Tefuro-kô).

(6) Rhodonite ore (Bara-kô).

(7) Alabandine ore (Ryûman-kô).

(8) Low grade ore of manganiferous hornfels type.

(9) Supergene manganese oxides ore (Ni-sanka mangan-kô). The grade of these ores and their important constituent minerals are shown in Table 1. It is very interesting to note that pyrochroite, manganosite and other manganese silicates hitherto known as very rare are very common in this mine and occur abundantly as important ore minerals. 
lent minerals.

\begin{tabular}{|c|c|c}
\hline Alabandine ore & $\begin{array}{c}\text { Manganiferous } \\
\text { hornfels ore }\end{array}$ & $\begin{array}{c}\text { Supergene man- } \\
\text { ganese oxide ore }\end{array}$ \\
\hline (Ryûman) & & (Ni-sanka) \\
\hline $44 \sim 54$ & $10 \sim 20$ & $80 \sim 85\left(\mathrm{MnO}_{2}\right)$ \\
\hline $1 \sim 5$ & & 5 \\
\hline $10 \sim 15$ & $40 \sim 60$ & - \\
\hline- & - & - \\
\hline-+ & - & - \\
\hline+++ & + & + \\
\hline+ & + & ++ \\
\hline- & - & ++ \\
\hline- & + & + \\
\hline+ & + & + \\
\hline+ & + & + \\
\hline+ & + & + \\
\hline
\end{tabular}


Table 1. Types of manganese ores of the Noda-Tamagawa deposits and their important constituent minerals.

\begin{tabular}{|c|c|c|c|c|c|c|c|c|c|c|}
\hline & Kind of ore & $\begin{array}{c}\text { Pyrochroite } \\
\text { ore }\end{array}$ & $\begin{array}{l}\text { Manganese- } \\
\text { carbonate ore }\end{array}$ & $\begin{array}{l}\text { Hausmannite } \\
\text { ore }\end{array}$ & Braunite ore & Tephroite ore & Rhodonite ore & Alabandine ore & $\begin{array}{c}\text { Manganiferous } \\
\text { hornfels ore }\end{array}$ & $\begin{array}{l}\text { Supergene man- } \\
\text { ganese oxide ore }\end{array}$ \\
\hline & (Local name) & $\begin{array}{l}\text { (Kibiman or } \\
\text { Kimiman) }\end{array}$ & (Tanman) & (Tetsuman) & & (Tefuro) & (Bara) & (Ryûman) & & (Ni-sanka) \\
\hline & $\mathrm{Mn} \%$ & $50 \sim 58$ & $40 \sim 50$ & $50 \sim 60$ & $50 \sim 55$ & $44 \sim 50, \quad 38 \sim 44$ & $26 \sim 32, \quad 20 \sim 25$ & $44 \sim 54$ & $10 \sim 20$ & $80 \sim 85\left(\mathrm{MnO}_{2}\right)$ \\
\hline & $\mathrm{Fe} \%$ & 0.5 & $0.5 \sim 1.5$ & $1 \sim 2$ & $2 \sim 5$ & $5 \sim 10$ & $3 \sim 5$ & $1 \sim 5$ & & \\
\hline & $\mathrm{Mn} \% \mathrm{SiO} \%$ & 5 & $5 \sim 7$ & 3 & $15 \sim 20$ & $25 \sim 30$ & $30 \sim 40$ & $10 \sim 15$ & $40 \sim 60$ & 5 \\
\hline Manganosite & 77.4 & ++ & + & ++ & - & - & - & - & - & - \\
\hline Pyrochroite & 62 & +++ & + & + & - & + & - & - & - & - \\
\hline Hydrohausmannite & 63 & ++ & + & + & - & + & - & - & - & 一. \\
\hline Hausmannite & 72 & + & + & $+t+$ & ++ & + & - & - & - & - \\
\hline Vredenburgite & $50 \sim 60$ & - & - & ++ & + & - & - & - & - & - \\
\hline Jacobsite & 23.8 & - & + & + & + & + & + & + & + & - \\
\hline Galaxite & 20 & + & + & + & + & + & - & + & - & - \\
\hline Pyrophanite & 36 & + & + & + & + & + & + & + & + & - \\
\hline Braunite & 63.6 & - & - & + & +++ & + & + & + & + & - \\
\hline Tephroite & 54.5 & $+t$ & ++ & ++ & ++ & +++ & + & ++ & + & - \\
\hline Alleghanyite & 56 & + & + & + & + & ++ & + & + & + & - \\
\hline Spessartine & 33 & - & - & - & + & + & ++ & ++ & + & - \\
\hline Rhodonite & 40 & - & - & - & + & ++ & +++ & ++ & ++ & - \\
\hline Pyroxmangite & 42 & - & - & - & + & ++ & ++ & + & ++ & - \\
\hline Bustamite & 35 & - & - & - & - & + & + & - & + & - \\
\hline Urbanite & $5 \sim 8$ & - & - & - & + & + & + & - & ++ & - \\
\hline Richterite & 10 & - & - & - & + & + & + & + & ++ & - \\
\hline Manganophyllite & $4 \sim 15$ & + & + & ++ & + & + & + & - & ++ & - \\
\hline Manganphlogopite & & ++ & + & + & - & + & - & + & + & - \\
\hline Bementite & 39 & + & + & + & + & + & + & + & + & - \\
\hline $\begin{array}{l}\text { Neotocite } \\
\text { (Penwithite) }\end{array}$ & $10 \sim 27$ & + & + & + & + & + & ++ & + & + & - \\
\hline Rhodochrosite & 47.8 & +++ & +++ & ++ & + & ++ & ++ & ++ & + & - \\
\hline Alabandine & 63.2 & + & + & - & + & + & + & +++ & + & - \\
\hline Baryte & 0 & + & + & + & + & + & + & + & + & + \\
\hline Pyrolusite & 63.2 & - & - & - & - & - & - & - & - & +++ \\
\hline $\begin{array}{l}\text { Cryptomelane } \\
\text { (Ramsdellite) }\end{array}$ & 63 & - & - & - & - & - & 一 & - & - & +++ \\
\hline Psilomelane & 63 & - & - & 一 & - & - & - & - & - & + \\
\hline Feldspar & 0 & - & - & - & + & + & + & + & + & + \\
\hline Quartz & 0 & - & - & - & + & - & + & - & + & ++ \\
\hline
\end{tabular}




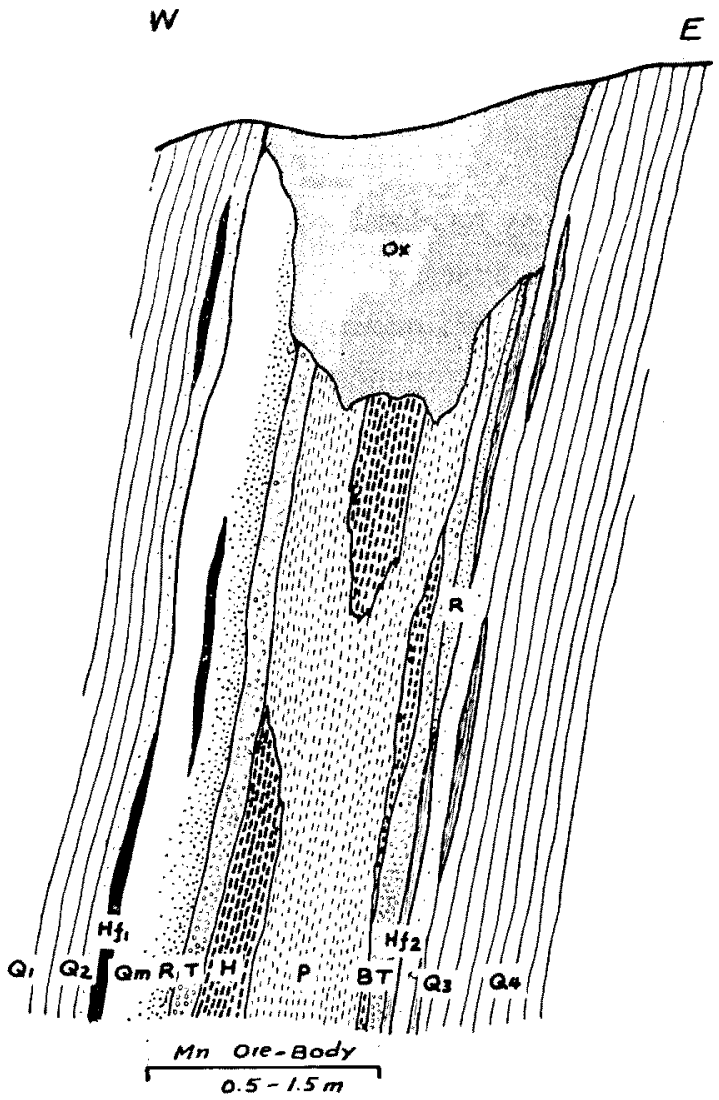

Fig. 4. Idealized cross section of the manganese ore zone of the Noda-Tamagawa mine, showing the bedded arrangement of manganese ores and country rocks. Vertical length of this section is diminished.

Ox: Oxidized zone consisting mainly of manganese dioxide ores.

$\mathrm{Hf}_{1}$ : Pelitic hornfels of the hanging wall (often uraniferous).

$\mathrm{Hf}_{2}$ : Pelitic hornfels of the foot wall (manganiferous).

$\mathrm{Q}_{1}$ : Thin-bedded meta-chert of the hanging wall.

$\mathrm{Q}_{2}$ : Thin-bedded meta-chert of the hanging wall in the manganese ore zone.

$\mathrm{Q}_{3}$ : Thin-bedded meta-chert of the foot wall in the manganese ore zone.

$Q_{4}$ : Thin-bedded meta-chert of the foot wall.

$\mathrm{Q}_{m}$ : Massive meta-chert containing small amounts of manganese minerals.

R: Rhodonite zone. T: Tephroite zone. H: Hausmannite ore. P: Pyrochroite-manganosite ore zone. 
Petrographically most of these ores show very fine banding structure. They occur usually in regular band in ore zones as shown in Fig. 4.

(B) Uranium deposits

Uranium deposits may be classified into the following two types: (1) vein and (2) hornfels types.

(1) Vein type: Uranium occurs in molybdenite-bearing quartz veins cutting the bedded manganese deposits along faults or joints. Although the width of the veins is usually narrow, comparatively high grade ores $(0.5 \% \mathrm{U})$ occur in localized parts of the veins. The reserve of uranium ores of this type is not large.

(2) Hornfels type: As shown in Fig. 4 uraniferous pelitic hornfels of lenticular form occurs always on the hanging wallside and is often associated with massive meta-chert.

The hornfels rich in uranium is macroscopically very dark due to higher content of carbonaceous matter and sulphides. Some uraniferous hornfelses contain as much as $0.15 \%$ U. Constant association of nickel, cobalt, vanadium, molybdenum with the uraniumbearing hornfels has been detected by fluorescent X-ray method. The characteristic occurrence and stratigraphic localization of the uranium ores suggest that the uranium was precipitated syngenetically together with iron, nickel, cobalt, molybdenum, etc.

(C) Copper-bearing pyrrhotite deposit of pyrometasomatic type

A copper-bearing pyrometasomatic pyrrhotite deposit occurs in the limestone area of the Noda-Tamagawa concession and has been known as the Shinmaida deposit since about 1920 . The pyrrhotite ores are included in lenticular blocks of saccharoidal limestone as shown in the geological map (Fig. 2). The principal minerals are garnet, sahlite, calcite, pyrrhotite and sphalerite. The ore contains $0.5 \sim 1 \%$ of copper in the form of chalcopyrite and $15 \sim 38 \%$ of iron mainly in the form of pyrrhotite.

(D) Gold-silver-bearing arsenopyrite-quartz-carbonate veins

In the course of the prospecting of the manganese deposits of 
the Misago ore zone, narrow veins contaning gold, silver and arsenopyrite were discovered. They occur along the strike faults in meta-cherts near the manganese ore-bodies.

\section{Parageneses of the minerals}

As the genetic history of the ores and rocks of the NodaTamagawa mining area is not so simple, the parageneses of minerals are very complex as well. The minerals hitherto found in this mining area, may be genetically classified into the following groups:

(1) Recrystallization products due to the thermal metamorphism.

(a) Minerals in manganese ores.

(b) Minerals in hornfelses.

(2) Pyrometasomatic products.

(a) Minerals in manganese ores.

(b) Minerals in limestone or "skarn".

(3) Pegmatitic or pneumatolytic products in or near the manganese ores.

(4) Hydrothermal products.

(a) Minerals replacing manganese ores.

(b) Minerals of the veins cutting manganese ores.

(c) Minerals of the gold-silver-bearing quartz-carbonate veins cutting hornfels.

(5) Supergene oxidation products.

(a) Minerals found in the oxidized zone of manganese deposits.

(b) Minerals found in the oxidized zone of copper-bearing pyrrhotite deposits.

In Table 2 the minerals have been arranged according to the abovementioned classification.

\section{(1) Recrystallization products}

As will be discussed later, most of the minerals constituting the manganese deposits may be recrystallization products from the syngenetic manganese carbonate and oxide ores due to thermal 
metamorphism of granite intrusions. Among many manganese minerals pyrochroite after manganosite, hausmannite, braunite, tephroite, rhodonite and rhodochrosite, make up nearly the whole mass of the manganese ores. The manganese ores which are considered to be recrystallization products show the characteristic mozaic texture under the microscope. Biotite, cordierite and andalusite are commonly found in pelitic hornfelses.

(2) Pyrometasomatic products

Pyrometasomatic products may be divided into two groups, manganese skarn and lime-silicate skarn.

Pyrometasomatic manganese skarn occurs along the contact between pegmatitic mass and manganese ore bodies. Rich manganese carbonate ores are often zonally bordered by massive tephroite and rhodonite.

Pyrometasomatic lime-silicate skarn occurs in limestone at Shinmaida and consists essentially of garnet, sahlite associated with pyrrhotite, chalcopyrite and sphalerite, etc.

The formation of these skarns may be attributed to metasomatic action of pegmatitic solutions derived from the later granitic magmas.

(3) Pegmatitic products near the manganese deposits

Peculiar pegmatitic rocks consisting mainly of barium-bearing feldspar, rhodonite, urbanite and richterite are often found on the foot-wall side of the Misago ore zone immediately adjacent to the manganese ores. Recently a new mineral, yoshimuraite, has been discovered by the author in this rock. Judging from the peculiar mineral association an intense interaction between manganese ores and pegmatitic solutions derived from the granitic magma might have taken place during the crystallization of the pegmatitic solutions. This peculiar pegmatitic facies may well correspond to the alkali facies of granite at granite-dolomite contacts in Skye described by C. E. Tilley ${ }^{14)}$ in 1949.

(4) Hydrothermal products 
Along faults and joints occur various kinds of hydrothermal veins which were probably formed during the later stage of granitic intrusion. The hydrothermal veins which cut the manganese deposits are rich in such manganese minerals as rhodonite, bementite, neotocite, mangancalcite, etc., while veins cutting siliceous rocks consist mainly of quartz.

Influence of chemical nature of the wall rocks to the vein stuff is very remarkable.

(5) Supergene oxidation products

Black manganese oxide ores were mined during the earlier stage of the exploitation of this mine. Most of supergene manganese ores have been exhausted. However, the occurrences of psilomelane and ramsdellite have been known in this mine.

Several supergene copper and iron minerals have also been discovered as shown in Table 2.

\section{Origin of ores}

As seen from the complex mineral parageneses of various kinds of rocks and ores of the Noda-Tamagawa mine, their origin may not be simple. Previous investigators like Yoshimura ${ }^{18}$ ) and Kitahara ${ }^{4)}$ offered metasomatic-emplacement hypothesis. They considered that main ore-bodies were formed by metasomatic emplacement due to hydrothermal action in the cherty rocks before the intrusion of the granitic rocks. However, Lee $\left.{ }^{6}\right)$ suggested the theory of high temperature hydrothermal replacement of selected chert in connection with granitic intrusion according to his study of the mineral paragenesis of ores in laboratory.

The manganese deposits found in the Chichibu Terrain in Japan are always bedded with rhythmic or massive cherts or meta-cherts. In less metamorphosed area the fine rhythmic sedimentary banding of constituent minerals is well observed. Manganese carbonate and oxide ores are often associated with radiolarian chert. The similar 
occurrence of manganese ore beds was described by N. L. Taliaferro ${ }^{13}$ ) in 1943.

The similar field relations between manganese ores and metacherts are also observed in the Noda-Tamagawa mining areas as explained before. But primary sedimentary textures of the manganese ores have sometimes been obliterated by later thermal metamorphism and also by invasion of pegmatitic and hydrothermal solutions derived from the later granitic magmas.

Taking all the field data and laboratory observations into consideration, it is concluded that the manganese ores were originally chemical sediments deposited syngenetically with the enclosing cherts and subsequently were metamorphosed.

As to the source of manganese and silica forming ores and cherty sediments, it is believed that both of them were probably derived from the same source such as submarine hot springs in geosynclinal basin. Therefore, the main part of the Noda-Tamagawa manganese deposits should be classed into the thermally metamorphosed exhalative sedimentary types.

According to the author's opinion uraniferous hornfelses were also originally chemical sediments containing the carbonaceous matter, nickel, cobalt, molybdenum, etc.

The Shinmaida copper-bearing pyrrhotite deposits may, however, belong to the ordinary pyrometasomatic type.

\section{Acknowledgements}

The author is grateful to President Y. Yokobori and other members of the staff of the Shinkohatsu Mining Company. Special thanks are due to Mr. K. Saida, General Manager, and T. Wada, A. Sato and K. Fukuda, mining geologists of the Company for the valuable information and for the aids during his field work. Thanks also are due to Mr. S. Yui, Dr. A. Kato, and Miss Den for their help during the preparation of this paper. 
Table 2. Paragenetic table of the minerals which have been identified in the Noda-Tamagawa mining area.

\begin{tabular}{|c|c|c|c|c|c|c|c|c|c|c|}
\hline \multirow[t]{2}{*}{ Occurrence } & \multicolumn{2}{|c|}{$\begin{array}{l}\text { Recrystallization products } \\
\text { due to thermal metamorphism }\end{array}$} & \multicolumn{2}{|c|}{$\begin{array}{c}\text { Pyrometasomatic products } \\
\text { (skarn) }\end{array}$} & \multirow{2}{*}{$\begin{array}{c}\begin{array}{c}\text { Pegmatitic or } \\
\text { pneumatolytic } \\
\text { products }\end{array} \\
\begin{array}{c}\text { In or near } \\
\text { manganese ore }\end{array} \\
\end{array}$} & \multicolumn{3}{|c|}{ Hydrothermal products } & \multicolumn{2}{|c|}{ Supergene oxidation products } \\
\hline & $\begin{array}{c}\text { In manganese } \\
\text { ores }\end{array}$ & In hornfels & $\begin{array}{c}\text { In manganese } \\
\text { ores }\end{array}$ & $\begin{array}{c}\text { In limestone } \\
\text { (skarn) }\end{array}$ & & $\begin{array}{l}\text { Replacement } \\
\text { mass }\end{array}$ & $\begin{array}{c}\text { Vein in man- } \\
\text { ganese deposit }\end{array}$ & $\begin{array}{l}\text { Vein in horn- } \\
\text { fels and chert }\end{array}$ & $\begin{array}{c}\text { Upper part of } \\
\text { the man- } \\
\text { ganese deposits }\end{array}$ & $\begin{array}{c}\text { Upper part of } \\
\text { the Cu-pyr- } \\
\text { rhotite deposits }\end{array}$ \\
\hline $\left.\mathrm{Mg}, \mathrm{Fe}^{*}\right)_{5} \mathrm{Si}_{8} \mathrm{O}_{22}(\mathrm{OH})_{2]}$ & - & - & - & + & - & - & - & - & - & - \\
\hline S ] & + & + & ++ & - & + & ++ & + & $\dot{-}$ & - & - \\
\hline $\left.\mathrm{O}_{8}\right]$ & - & + & - & - & + & + & - & + & - & - \\
\hline $\left.\left.\mathrm{e}^{\cdots}\right)_{2}\left(\mathrm{R}, \mathrm{Al}, \mathrm{Fe}{ }^{\cdots}\right)_{3} \mathrm{Si}_{3} \mathrm{O}_{12} \mathrm{OH}\right]$ & + & - & + & - & + & -- & - & - & - & - \\
\hline $\left.\mathrm{In}_{5} \mathrm{Si}_{2} \mathrm{O}_{8}(\mathrm{OH})_{2}\right]$ & ++ & - & + & - & - & - & - & - & - & - \\
\hline$\left.{ }_{3} \mathrm{Al}_{2} \mathrm{Si}_{3} \mathrm{O}_{12}\right]$ & - & + & - & - & - & - & - & - & - & - \\
\hline $\left.\mathrm{SiO}_{5}\right]$ & - & ++ & - & - & - & - & - & - & - & - \\
\hline $\mathrm{e}_{2} \mathrm{Si}_{3} \mathrm{O}_{12}$ & - & + & - & +++ & - & - & - & - & - & - \\
\hline $\left.\left.\mathrm{O}_{4}\right)_{3} \mathrm{~F}\right]$ & - & + & - & + & + & - & - & - & - & - \\
\hline eAsS] & - & - & + & + & - & + & ++ & +++ & - & - \\
\hline ise $\left[(\mathrm{KSi}, \mathrm{BaAI}) \mathrm{AlSi}_{2} \mathrm{O}_{8}\right]$ & + & + & + & - & ++ & - & - & - & - & - \\
\hline & + & - & + & - & - & + & ++ & - & - & - \\
\hline $\left.\mathrm{SiO}_{3} \frac{1}{2} \mathrm{H}_{2} \mathrm{O}\right]$ & ++ & - & + & - & + & + & ++ & - & - & - \\
\hline $\left.\mathrm{Fe} \cdot, \mathrm{Al}, \mathrm{Fe}^{\cdots \cdots}\right)_{4-6}(\mathrm{Si}, \mathrm{Al})_{8} \mathrm{O}_{20}(\mathrm{OH})_{4} \mathrm{~J}$ & - & +++ & - & - & + & - & - & - & - & - \\
\hline$\left.S_{4}\right]$ & - & - & - & + & - & - & + & - & - & + \\
\hline $\left.\mathrm{Mn}_{6}{ }_{6} \mathrm{SiO}_{12}\right]$ & ++ & + & + & - & + & - & - & $\cdots$ & - & - \\
\hline , Ca) $\left.\mathrm{SiO}_{3}\right]$ & + & - & + & - & + & - & - & - & - & - \\
\hline 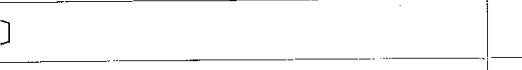 & - & + & - & +++ & - & - & 一 & ++ & - & - \\
\hline S] & - & - & - & + & - & - & - & - & - & + \\
\hline $\left.\mathrm{uFFeS}_{2}\right]$ & - & + & + & + & + & + & + & ++ & - & - \\
\hline $\begin{array}{l}{ }_{4}^{4} \mathrm{Al}_{2}(\mathrm{OH})_{8} \cdot \mathrm{Al}_{2} \overline{\mathrm{Si}}_{2} \mathrm{O}_{12^{-}} \\
\left.{ }_{6}(\mathrm{OH})_{8} \mathrm{Si}_{4} \mathrm{O}_{10}\right]\end{array}$ & - & + & + & + & + & + & + & ++ & - & 一 \\
\hline sS] & - & + & - & - & - & + & + & $+?$ & - & - \\
\hline & - & - & - & - & - & - & - & - & - & + \\
\hline , $\left.\mathrm{Fe})_{2} \mathrm{Al}_{4} \mathrm{Si}_{5} \mathrm{O}_{18}\right]$ & - & ++ & - & -- & - & - & - & - & - & - \\
\hline $\left.\mathrm{e}_{2} \mathrm{~S}_{3}\right]$ & - & - & - & + & - & - & - & - & - & - \\
\hline$\left.(\mathrm{Fe}, \mathrm{Mn}, \mathrm{Mg})_{7} \mathrm{Si}_{8} \mathrm{O}_{22}(\mathrm{OH})_{2}\right]$ & + & + & + & - & - & - & - & - & - & - \\
\hline $\left.\mathrm{aSi}_{2} \mathrm{O}_{6}\right]$ & - & + & - & + & - & - & - & - & - & - \\
\hline $\left.1, \mathrm{Fe})_{3} \mathrm{Si}_{3} \mathrm{O}_{12} \mathrm{OH}\right]$ & - & + & - & ++ & - & - & - & - & - & - \\
\hline $\left.\mathrm{I}_{2} \mathrm{O}_{4}\right]$ & + & - & - & - & - & - & - & - & - & - \\
\hline & - & - & + & + & - & + & ++ & ++ & - & - \\
\hline iAsS] & - & + & - & - & - & - & $+?$ & - & - & - \\
\hline $\left.\mathrm{Al}_{2} \mathrm{Si}_{3} \mathrm{O}_{12}\right]$ & - & - & - & ++ & - & - & - & - & - & - \\
\hline $\left.\mathrm{Mn}_{3} \mathrm{O}_{4}\right]$ & +++ & - & $+?$ & - & - & - & - & - & - & - \\
\hline $\left.\mathrm{CaFeSi}_{2} \mathrm{O}_{6}\right]$ & - & - & - & ++ & - & - & - & - & - & - \\
\hline S & - & + & - & - & - & - & - & - & - & - \\
\hline $\left.\mathrm{Si}, \mathrm{BaAl}) \mathrm{AlSi}_{2} \mathrm{O}_{8}\right]$ & + & + & + & - & + & - & - & - & - & - \\
\hline nite $\left[\mathrm{Mn}_{3-x}(\mathrm{O}, \mathrm{OH})_{4}\right]$ & ++ & - & - & - & - & - & - & - & + & - \\
\hline $\left.\mathrm{Mg}, \mathrm{Fe})_{2} \mathrm{Al}_{4} \mathrm{Si}_{9} \mathrm{O}_{34}(\mathrm{OH})_{4}\right]$ & - & - & - & ++ & - & - & - & - & - & - \\
\hline $\mathrm{Fe} *, \mathrm{Mg})\left(\mathrm{Fe}^{\cdots,}, \mathrm{Mn}_{2} \mathrm{O}_{4}\right]$ & + & + & + & - & - & - & - & - & - & - \\
\hline $\left.\mathrm{O}_{3} \cdot n \mathrm{H}_{2} \mathrm{O}\right]$ & - & - & - & - & - & - & - & - & + & +++ \\
\hline$\left.{ }_{3} \mathrm{O}_{4}\right]$ & - & + & - & + & - & - & - & - & - & - \\
\hline $\left.\mathrm{CO}_{3}(\mathrm{OH})_{2}\right]$ & - & - & - & - & - & - & - & - & + & ++ \\
\hline$\left[(\mathrm{Mn}, \mathrm{Ca}) \mathrm{CO}_{3}\right]$ & + & + & + & - & - & + & ++ & + & - & - \\
\hline te $\left[\mathrm{K}_{2} \mathrm{Mn}_{5} \mathrm{Al}_{4} \mathrm{Si}_{5} \mathrm{O}_{10}(\mathrm{OH})_{4}\right]$ & + & + & + & 一 & + & - & - & - & - & - \\
\hline pite $\left[\mathrm{K}(\mathrm{Mg}, \mathrm{Mn})_{3} \mathrm{AlSi}_{3} \mathrm{O}_{10}(\mathrm{OH})_{2}\right]$ & + & - & - & - & - & - & - & - & - & - \\
\hline $\mathrm{MnO}]$ & ++ & - & - & - & - & - & - & - & - & - \\
\hline $\left.\mathrm{S}_{2}\right]$ & - & + & - & + & - & - & - & - & - & - \\
\hline $\left.\mathrm{MoS}_{2}\right]$ & $+?$ & $+?$ & + & $+?$ & + & - & - & - & $\cdots$ & - \\
\hline $\left.\mathrm{Al}_{3} \mathrm{Si}_{3} \mathrm{O}_{10}(\mathrm{OH})_{2}\right]$ & - & ++ & - & - & - & - & - & - & - & - \\
\hline$\left.{ }_{2} \mathrm{Fe}_{2} \mathrm{Si}_{4} \mathrm{O}_{13} \cdot 6 \mathrm{H}_{2} \mathrm{O}\right]$ & + & + & + & - & + & ++ & ++ & - & - & - \\
\hline s] & - & + & - & - & - & + & + & $+?$ & - & - \\
\hline$(\mathrm{Fe}, \mathrm{Ni}) \mathrm{S}_{2}$ & - & ++ & + & - & - & - & - & - & - & - \\
\hline$\left[{ }_{2} \mathrm{O}\right]$ & - & - & - & - & - & + & + & + & + & - \\
\hline $\left.\mathrm{AlSi}_{3} \mathrm{O}_{8}\right]$ & - & ++ & + & - & ++ & - & - & - & - & - \\
\hline$\left[\mathrm{Mn}_{10} \mathrm{Si}_{12} \mathrm{O}_{26}(\mathrm{OH})_{16}\right] ?$ & $+?$ & - & - & - & - & $+?$ & - & - & - & - \\
\hline $\left.\mathrm{MnSiO}{ }_{3} \cdot 2 \mathrm{H}_{2} \mathrm{O}\right]$ & ++ & + & + & + & + & +++ & ++ & ++ & - & 一 \\
\hline$\left.(\mathrm{Fe}, \mathrm{Ni})_{9} \mathrm{~S}_{8}\right]$ & - & + & - & - & - & + & - & - & - & - \\
\hline e $\left[(\mathrm{Mn}, \mathrm{Mg})_{2} \mathrm{SiO}_{4}\right]$ & ++ & - & + & - & - & - & - & - & - & - \\
\hline
\end{tabular}


$\mathrm{e}_{2} \mathrm{O}_{3-}$

$\left[(\mathrm{KSi}, \mathrm{BaAl}) \mathrm{AlSi}_{2} \mathrm{O}_{8}\right]$

annite $\left[\mathrm{Mn}_{3-x}(\mathrm{O}, \mathrm{OH})_{4}\right]$

${ }_{10}\left(\mathrm{Mg}, \mathrm{Fe}_{2} \mathrm{Al}_{4} \mathrm{Si}_{9} \mathrm{O}_{34}(\mathrm{OH})_{4}\right]$

$\mathrm{Mn}, \mathrm{Fe} \cdot, \mathrm{Mg})\left(\mathrm{Fe} \cdots, \mathrm{Mn}_{2} \mathrm{O}_{4}\right]$

$\mathrm{C}_{2} \mathrm{O}_{3} \cdot n \mathrm{H}_{2} \mathrm{OJ}$

$\left.\mathrm{Fe}_{3} \mathrm{O}_{4}\right]$

$\left.\mathrm{Cu}_{2} \mathrm{CO}_{3}(\mathrm{OH})_{2}\right]$

te $\left[(\mathrm{Mn}, \mathrm{Ca}) \mathrm{CO}_{3}\right]$

Ilite $\left[\mathrm{K}_{2} \mathrm{Mn}_{5} \mathrm{Al}_{4} \mathrm{Si}_{5} \mathrm{O}_{10}(\mathrm{OH})_{4}\right]$

gopite $\left[\mathrm{K}(\mathrm{Mg}, \mathrm{Mn})_{3} \mathrm{AlSi}_{3} \mathrm{O}_{10}(\mathrm{OH})_{2}\right]$

[MnO]

$\left.\mathrm{PS}_{2}\right]$

$\left[\mathrm{MoS}_{2}\right]$

$\left.\mathrm{KAl}_{3} \mathrm{Si}_{3} \mathrm{O}_{10}(\mathrm{OH})_{2}\right]$

$\left.\mathrm{An}_{2} \mathrm{Fe}_{2} \mathrm{Si}_{4} \mathrm{O}_{13} \cdot 6 \mathrm{H}_{2} \mathrm{O}\right]$

$[\mathrm{iAs}]$

$\left[(\mathrm{Fe}, \mathrm{Ni}) \mathrm{S}_{2}\right.$

$\left.{ }_{2 \mathrm{H}} \mathrm{O} \mathrm{O}\right]$

$\left.\mathrm{KAlSi}_{3} \mathrm{O}_{8}\right]$

e $\left[\mathrm{Mn}_{10} \mathrm{Si}_{12} \mathrm{O}_{26}(\mathrm{OH})_{16}\right]$ ?

$\left[\mathrm{MnSiO}_{3} \cdot 2 \mathrm{H}_{2} \mathrm{O}\right]$

$\left[(\mathrm{Fe}, \mathrm{Ni})_{9} \mathrm{~S}_{8}\right]$

te $\left[\left(\mathrm{Mn}, \mathrm{Mg}_{2} \mathrm{SiO}_{4}\right]\right.$

$\left[(\mathrm{Ba}, \mathrm{Mn} \cdot) \mathrm{Mn}^{\cdots \cdot} \cdot{ }_{4} \mathrm{O}_{8}(\mathrm{OH})_{2}\right]$

$\left.\mathrm{MnO}_{2}\right]$

$\left[\mathrm{MnTiO}_{3}\right]$

te $\left[(\mathrm{Mn}, \mathrm{Fe}, \mathrm{Ca}) \mathrm{SiO}_{3}\right]$

$\left.\mathrm{Fe}_{1-x} \mathrm{~S}\right]$

$\mathrm{MnO}_{2}$

te $\left[\mathrm{MnCO}_{3}\right]$

$\left.(\mathrm{Mn}, \mathrm{Ca}) \mathrm{SiO}_{3}\right]$

$\left.(\mathrm{Na}, \mathrm{K})_{2}(\mathrm{Mg}, \mathrm{Mn}, \mathrm{Ca}, \mathrm{Fe})_{6} \mathrm{Si}_{8} \mathrm{O}_{20}(\mathrm{OH})_{2}\right]$

$\left.(\mathrm{Mg}, \mathrm{Fe}) \mathrm{Si}_{2} \mathrm{O}_{6}\right]$

$\left.\mathrm{Al}_{3} \mathrm{Si}_{3} \mathrm{O}_{10}(\mathrm{OH})_{2}\right]$

$\left[\mathrm{Mn}_{3} \mathrm{Al}_{2} \mathrm{Si}_{3} \mathrm{O}_{12}\right]$

$\mathrm{ZnS}]$

$\left.\mathrm{TiSiO}_{5}\right]$

$\left.\mathrm{Mn}_{2} \mathrm{SiO}_{4}\right]$

e $\left[\mathrm{Cu}_{3}(\mathrm{Sb}, \mathrm{As}) \mathrm{S}_{3}\right]$

$\left[\left(\mathrm{Na}_{1} \mathrm{Ca}\right)(\mathrm{Mg}, \mathrm{Fe} \cdot, \mathrm{Al})_{3}\left(\mathrm{Al}, \mathrm{Fe}^{\cdots \cdot)_{6}-}\right.\right.$

$\frac{\mathrm{B}_{3} \mathrm{Si}_{6} \mathrm{O}_{27}(\mathrm{O}, \mathrm{OH}, \mathrm{F})_{4}}{\left.\mathrm{Ca}_{2} \mathrm{Mg}_{5} \mathrm{Si}_{8} \mathrm{O}_{22}(\mathrm{OH})_{2}\right]}$

$\left.\mathrm{UO}_{2}\right]$

$\left.\mathrm{Na}, \mathrm{Fe} \cdot \cdot, \mathrm{Ca}, \mathrm{Mg}) \mathrm{Si}_{2} \mathrm{O}_{6}\right]$

gite $\left[(\mathrm{Mn}, \mathrm{Fe})_{8} \mathrm{O}_{4}-(\mathrm{Fe}, \mathrm{Mn})_{3} \mathrm{O}_{4}\right]$

$\left[\mathrm{CaSiO}_{3}\right]$

$\left[(\mathrm{Ba}, \mathrm{Sr})_{4} \mathrm{Mn}_{4} \mathrm{Ti}_{2}\left(\mathrm{SiO}_{4}\right)_{4}\right.$

$\left.\left[(\mathrm{P}, \mathrm{S}) \mathrm{O}_{4}\right]_{2}(\mathrm{OH}, \mathrm{Cl})_{3}\right]$

$\left.\mathrm{iO}_{4}\right]$

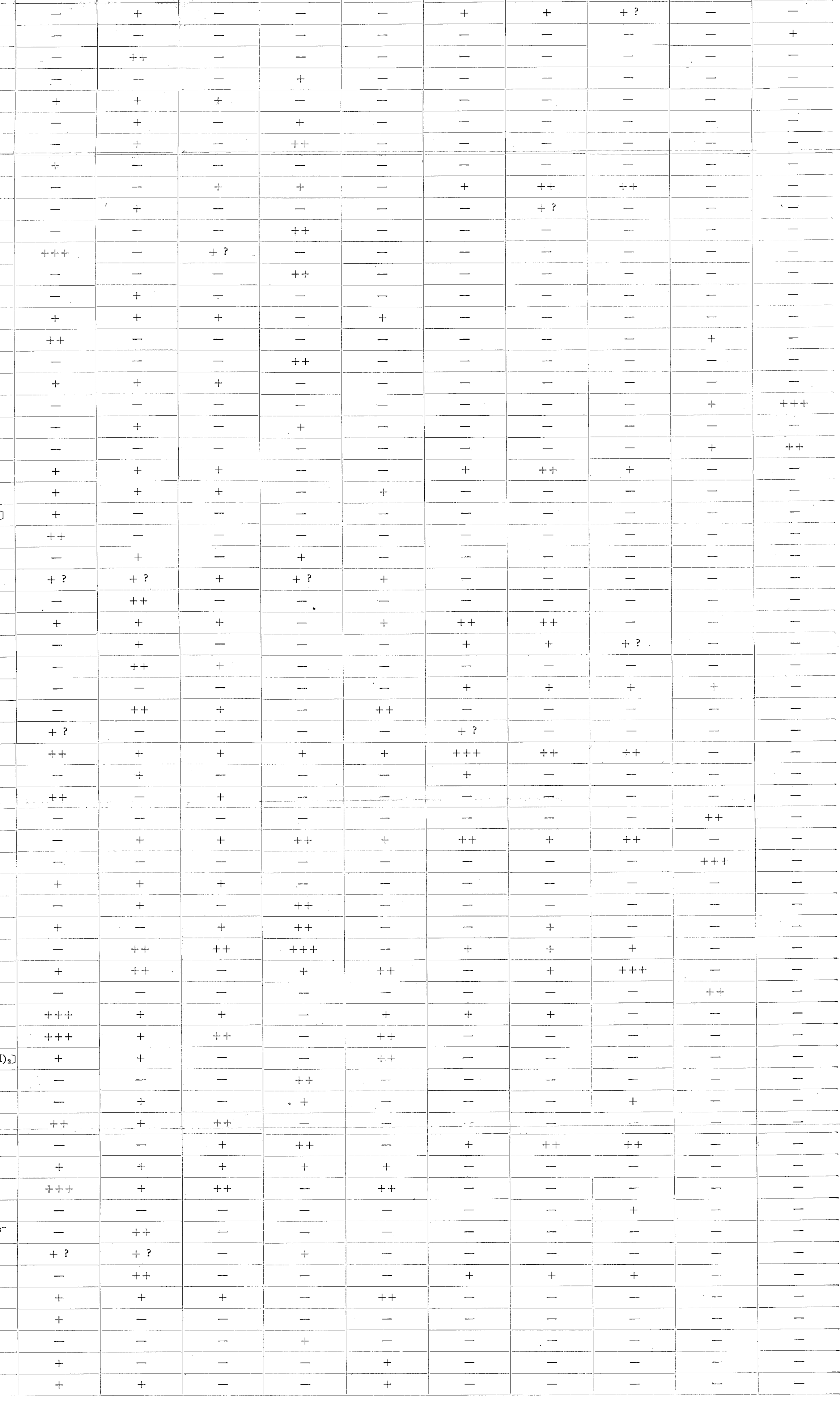


Cobaltite $[\mathrm{CoAsS}]$

Copper $[\mathrm{Cu}]$

Cordierite $\left[\mathrm{Mg}, \mathrm{Fe}_{2} \mathrm{Al}_{4} \mathrm{Si}_{5} \mathrm{O}_{18}\right]$

Cubanite $\left[\mathrm{CuFe}_{2} \mathrm{~S}_{3}\right]$

Dannemorite $\left[(\mathrm{Fe}, \mathrm{Mn}, \mathrm{Mg})_{7} \mathrm{Si}_{8} \mathrm{O}_{22}(\mathrm{OH})_{2}\right]$

Diopside $\left[\mathrm{MgCaSi}_{2} \mathrm{O}_{6}\right]$

Epidote $\left[\mathrm{Ca}_{2}(\mathrm{Al}, \mathrm{Fe})_{3} \mathrm{Si}_{3} \mathrm{O}_{12} \mathrm{OH}\right]$

Galaxite $\left[\mathrm{MnAl}_{2} \mathrm{O}_{4}\right]$

Galena $[\mathrm{PbS}]$

Gersdorffite [NiAsS]

Grossular $\left[\mathrm{Ca}_{3} \mathrm{Al}_{2} \mathrm{Si}_{3} \mathrm{O}_{12}\right]$

Hausmannite $\left[\mathrm{Mn}_{3} \mathrm{O}_{4}\right]$

Hedenbergite $\left[\mathrm{CaFeSi}_{2} \mathrm{O}_{6}\right]$

Hematite $\left[\mathrm{Fe}_{2} \mathrm{O}_{3}\right]$

Hyalophane [(KSi, BaAl) $\mathrm{AlSi}_{2} \mathrm{O}_{8}$ ]

Hydrohausmannite $\left[\mathrm{Mn}_{3-x}(\mathrm{O}, \mathrm{OH})_{4}\right]$

Idocrase $\left[\mathrm{Ca}_{10}(\mathrm{Mg}, \mathrm{Fe})_{2} \mathrm{Ai}_{4} \mathrm{Si}_{9} \mathrm{O}_{34}(\mathrm{OH})_{4}\right]$

Jacobsite $\left[\left(\mathrm{Mn}, \mathrm{Fe} \mathrm{e}^{-}, \mathrm{Mg}\right)\left(\mathrm{Fe} \cdot \cdots, \mathrm{Mn}_{2} \mathrm{O}_{4}\right]\right.$

Limonite $\left[\mathrm{Fe}_{2} \mathrm{O}_{3} \cdot n \mathrm{H}_{2} \mathrm{O}\right]$

Magnetite $\left[\mathrm{Fe}_{3} \mathrm{O}_{4}\right]$

Malachite $\left[\mathrm{Cu}_{2} \mathrm{CO}_{3}(\mathrm{OH})_{2}\right]$

Mangancalcite $\left[(\mathrm{Mn}, \mathrm{Ca}) \mathrm{CO}_{\mathbf{3}}\right]$

Manganophyllite $\left[\mathrm{K}_{2} \mathrm{Mn}_{5} \mathrm{Al}_{4} \mathrm{Si}_{5} \mathrm{O}_{10}(\mathrm{OH})_{4}\right]$

Manganphlogopite $\left[\mathrm{K}(\mathrm{Mg}, \mathrm{Mn})_{3} \mathrm{AlSi}_{3} \mathrm{O}_{10}(\mathrm{OH})_{2}\right]$

Manganosite [MnO]

Marcasite $\left[\mathrm{FeS}_{2}\right]$

Molybdenite $\left[\mathrm{MoS}_{2}\right]$

Muscovite $\left[\mathrm{KAl}_{3} \mathrm{Si}_{3} \mathrm{O}_{10}(\mathrm{OH})_{2}\right]$

Neotocite $\left[\mathrm{Mn}_{2} \mathrm{Fe}_{2} \mathrm{Si}_{4} \mathrm{O}_{13} \cdot 6 \mathrm{H}_{2} \mathrm{O}\right]$

Niccolite [NiAs]

Nickelpyrite $\left[(\mathrm{Fe}, \mathrm{Ni}) \mathrm{S}_{2}\right.$

Opal $\left[\mathrm{SiO}_{2} \cdot n \mathrm{H}_{2} \mathrm{O}\right]$

Orthoclase $\left[\mathrm{KAlSi}_{3} \mathrm{O}_{8}\right]$

Parsettensite $\left[\mathrm{Mn}_{10} \mathrm{Si}_{12} \mathrm{O}_{26}(\mathrm{OH})_{16}\right]$ ?

Penwithite $\left[\mathrm{MnSiO}_{3} \cdot 2 \mathrm{H}_{2} \mathrm{O}\right]$

Pentlandite $\left[(\mathrm{Fe}, \mathrm{Ni})_{8} \mathrm{~S}_{8}\right]$

Picrotephroite [( $\left.\mathrm{Mn}, \mathrm{Mg})_{2} \mathrm{SiO}_{4}\right]$

Psilomelane [( $\left.\left.\mathrm{Ba}, \mathrm{Mn}^{*}\right) \mathrm{Mn}^{*} \cdot{ }_{4} \mathrm{O}_{8}(\mathrm{OH})_{2}\right]$

Pyrite $\left[\mathrm{FeS}_{2}\right]$

Pyrolusite $\left[\mathrm{MnO}_{2}\right]$

Pyrophanite $\left[\mathrm{MnTiO}_{3}\right]$

Pyroxene

Pyroxmangite [(Mn, $\mathrm{Fe}, \mathrm{Ca}) \mathrm{SiO}_{3}$ ]

Pyrrhotite $\left[\mathrm{Fe}_{1-x} \mathrm{~S}\right]$

Quartz $\left[\mathrm{SiO}_{2}\right]$

Ramsdellite $\left[\mathrm{MnO}_{2}\right]$

Rhodochrosite $\left[\mathrm{MnCO}_{8}\right]$

Rhodonite [(Mn, $\mathrm{Ca}) \mathrm{SiO}_{3}$ ]

Richterite $\left[(\mathrm{Na}, \mathrm{K})_{2}(\mathrm{Mg}, \mathrm{Mn}, \mathrm{Ca}, \mathrm{Fe})_{6} \mathrm{Si}_{8} \mathrm{O}_{20}(\mathrm{OH})_{2}\right]$

Sahlite $\left[\mathrm{Ca}(\mathrm{Mg}, \mathrm{Fe}) \mathrm{Si}_{2} \mathrm{O}_{6}\right]$

Sericite $\left[\mathrm{KAl}_{3} \mathrm{Si}_{3} \mathrm{O}_{10}(\mathrm{OH})_{2}\right]$

Spessartine $\left[\mathrm{Mn}_{3} \mathrm{Al}_{2} \mathrm{Si}_{3} \mathrm{O}_{12}\right]$

Sphalerite $[\mathrm{ZnS}]$

Sphene $\left[\mathrm{CaTiSiO}_{5}\right]$

Tephroite $\left[\mathrm{Mn}_{2} \mathrm{SiO}_{4}\right]$

Tetrahedrite $\left[\mathrm{Cu}_{3}(\mathrm{Sb}, \mathrm{As}) \mathrm{S}_{3}\right]$

Tourmaline $\left[(\mathrm{Na}, \mathrm{Ca})(\mathrm{Mg}, \mathrm{Fe} \cdot, \mathrm{Al})_{3}\left(\mathrm{Al}, \mathrm{Fe} \mathrm{F}^{-{ }^{-}}\right)^{-}\right.$

Tremolite $\left[\mathrm{Ca}_{2} \mathrm{Mg}_{5} \mathrm{Si}_{8} \mathrm{O}_{22}(\mathrm{OH})_{2}\right]$

Uraninite $\left[\mathrm{UO}_{2}\right]$

Urbanite $\left[\left(\mathrm{Na}, \mathrm{Fe}{ }^{\cdots}, \overline{\mathrm{Ca}}, \mathrm{Mg}\right) \mathrm{Si}_{2} \mathrm{O}_{6}\right]$

$\beta$-Vredenburgite $\left[(\mathrm{Mn}, \mathrm{Fe})_{8} \mathrm{O}_{4}-(\mathrm{Fe}, \mathrm{Mn})_{3} \mathrm{O}_{4}\right]$

Wollastonite $\left[\mathrm{CaSiO}_{8}\right]$ Yoshimuraite $\left[(\mathrm{Ba}, \mathrm{Sr})_{4} \mathrm{Mn}_{4} \mathrm{Ti}_{2}\left(\mathrm{SiO}_{4}\right)_{4}\right.$
$\left.\left[(\mathrm{P}, \mathrm{S}) \mathrm{O}_{4}\right]_{2}(\mathrm{OH}, \mathrm{Cl})_{3}\right]$

Zircon $\left[\mathrm{ZrSiO}_{4}\right]$

\begin{tabular}{|c|c|c|c|c|c|}
\hline- & - & - & + & + & $+?$ \\
\hline- & - & - & - & - & - \\
\hline- & - & - & - & - & - \\
\hline- & + & $\cdots$ & - & - & - \\
\hline+ & - & - & - & - & - \\
\hline- & + & - & - & - & - \\
\hline- & ++ & - & - & - & - \\
\hline- & - & - & - & - & - \\
\hline+ & + & - & + & ++ & ++ \\
\hline- & - & - & - & $+?$ & - \\
\hline- & ++ & - & - & - & - \\
\hline$+?$ & - & - & - & - & - \\
\hline- & ++ & - & - & - & - \\
\hline- & - & - & - & - & - \\
\hline+ & - & + & - & - & - \\
\hline- & - & - & - & - & - \\
\hline- & ++ & - & - & - & - \\
\hline+ & - & - & - & - & - \\
\hline- & - & - & - & - & - \\
\hline- & + & - & - & - & - \\
\hline- & - & - & - & - & - \\
\hline+ & - & - & + & ++ & + \\
\hline+ & - & + & - & - & - \\
\hline- & - & - & - & - & - \\
\hline- & - & - & - & - & - \\
\hline- & + & - & - & - & - \\
\hline+ & $+?$ & + & - & - & - \\
\hline- & - & - & - & - & - \\
\hline+ & -- & + & ++ & ++ & - \\
\hline- & - & - & + & + & $+?$ \\
\hline+ & - & - & - & - & - \\
\hline- & - & - & + & + & + \\
\hline+ & - & ++ & - & - & - \\
\hline- & - & - & $+?$ & - & - \\
\hline+ & + & + & +++ & ++ & ++ \\
\hline- & - & - & + & - & - \\
\hline+ & $=$ & - & - & - & - \\
\hline- & - & - & - & - & - \\
\hline+ & ++ & + & ++ & + & ++ \\
\hline- & - & - & - & - & - \\
\hline+ & - & - & - & - & - \\
\hline- & ++ & - & - & - & - \\
\hline+ & ++ & - & - & + & - \\
\hline++ & +++ & - & + & + & + \\
\hline- & + & ++ & - & + & +++ \\
\hline- & - & - & - & - & - \\
\hline+ & - & + & + & + & - \\
\hline++ & - & ++ & - & - & - \\
\hline- & - & ++ & - & - & - \\
\hline- & ++ & - & - & - & - \\
\hline- & $\cdot+$ & - & - & - & + \\
\hline++ & - & - & - & 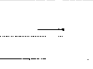 & - \\
\hline+ & ++ & - & + & ++ & ++ \\
\hline+ & + & + & - & - & - \\
\hline++ & - & ++ & - & - & - \\
\hline- & - & - & - & - & + \\
\hline- & - & - & - & - & - \\
\hline- & + & - & - & - & - \\
\hline- & - & - & + & + & + \\
\hline+ & - & ++ & - & - & - \\
\hline- & - & - & - & - & - \\
\hline- & + & - & - & - & - \\
\hline- & - & + & - & - & - \\
\hline- & - & + & - & - & - \\
\hline
\end{tabular}


Table 2. Paragenetic table of the minerals which have been identified in the Noda-Tamagawa mining area.

Occurrence

\section{Mineral}

Actinolite $\left[\mathrm{Ca}_{2}\left(\mathrm{Mg}, \mathrm{Fe}^{\cdot *}\right)_{5} \mathrm{Si}_{8} \mathrm{O}_{22}(\mathrm{OH})_{2}\right]$

Aläbandine [MnS]

Albite $\left[\mathrm{NaAlSi}_{3} \mathrm{O}_{8}\right]$

Allanite $\left[\left(\mathrm{Ca}, \mathrm{Fe}^{*}\right)_{2}\left(\mathrm{R}, \mathrm{Al}, \mathrm{Fe} \mathrm{e}^{\cdots}\right)_{3} \mathrm{Si}_{3} \mathrm{O}_{12} \mathrm{OH}\right]$

Alleghanyite $\left[\mathrm{Mn}_{5} \mathrm{Si}_{2} \mathrm{O}_{8}(\mathrm{OH})_{2}\right]$

Almandine $\left[\mathrm{Fe} \cdot{ }_{3} \mathrm{Al}_{2} \mathrm{Si}_{3} \mathrm{O}_{12}\right]$

Andalusite $\left[\mathrm{Al}_{2} \mathrm{SiO}_{5}\right]$

Andradite $\left[\mathrm{Ca}_{3} \mathrm{Fe}_{2}{ }_{2} \mathrm{Si}_{3} \mathrm{O}_{12}\right]$

Apatite $\left[\mathrm{Ca}_{5}\left(\mathrm{PO}_{4}\right)_{3} \mathrm{~F}\right]$

Arsenopyrite [FeAsS]

Barium orthoclase [(KSi, BaAl) $\left.\mathrm{AlSi}_{2} \mathrm{O}_{8}\right]$

Baryte $\left[\mathrm{BaSO}_{4}\right]$

Bementite $\left[\mathrm{Mn} \mathrm{SiO} \mathrm{Si}_{3} \frac{1}{2} \mathrm{H}_{2} \mathrm{O}\right]$

Biotite $\left[\mathrm{K}_{2}\left(\mathrm{Mg}, \mathrm{Fe}{ }^{*}, \mathrm{Al}, \mathrm{Fe}{ }^{\cdots *}\right)_{4-6}(\mathrm{Si}, \mathrm{Al})_{8} \mathrm{O}_{20}(\mathrm{OH})_{4}\right]$

Bornite $\left[\mathrm{Cu}_{5} \mathrm{FeS}_{4}\right]$

Braunite $\left[\mathrm{Mn} \cdot \mathrm{Mn}^{\prime}{ }_{6} \mathrm{SiO}_{12}\right]$

Bustamite [( $\left.\mathrm{Mn}, \mathrm{Ca}) \mathrm{SiO}_{3}\right]$

Calcite $\left[\mathrm{CaCO}_{3}\right]$

Chalcocite $\left[\mathrm{Cu}_{2} \mathrm{~S}\right]$

Chalcopyrite $\left[\mathrm{CuFeS}_{2}\right]$

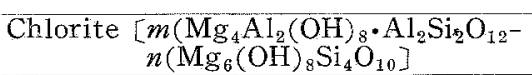

Cobaltite [CoAss]

Copper [Cu]

Cordierite $\left.[\mathrm{Mg}, \mathrm{Fe})_{2} \mathrm{Al}_{4} \mathrm{Si}_{5} \mathrm{O}_{18}\right]$

Cubanite $\left[\mathrm{CuFe}_{2} \mathrm{~S}_{3}\right]$

Dannemorite [ $\left.(\mathrm{Fe}, \mathrm{Mn}, \mathrm{Mg})_{7} \mathrm{Si}_{8} \mathrm{O}_{22}(\mathrm{OH})_{2}\right]$

Diopside $\left[\mathrm{MgCaSi}_{2} \mathrm{O}_{6}\right]$

Epidote $\left[\mathrm{Ca}_{2}(\mathrm{Al}, \mathrm{Fe})_{3} \mathrm{Si}_{3} \mathrm{O}_{12} \mathrm{OH}\right]$

Galaxite $\left[\mathrm{MnAl}_{2} \mathrm{O}_{4}\right]$

Galena $[\mathrm{PbS}]$

Gersdorffite [NiAsS]

Grossular $\left[\mathrm{Ca}_{3} \mathrm{Al}_{2} \mathrm{Si}_{3} \mathrm{O}_{12}\right]$

Hausmannite $\left[\mathrm{Mn}_{3} \mathrm{O}_{4}\right]$

Hedenbergite $\left[\mathrm{CaFeSi}_{2} \mathrm{O}_{6}\right]$

Hematite $\left[\mathrm{Fe}_{2} \mathrm{O}_{3}\right]$

Hyalophane $\left[(\mathrm{KSi}, \mathrm{BaAl}) \mathrm{AlSi}_{2} \mathrm{O}_{8}\right]$

Hydrohausmannite $\left[\mathrm{Mn}_{\mathbf{3}-x}(\mathrm{O}, \mathrm{OH})_{4}\right]$

Idacrase $\left[\mathrm{Ca}_{10}(\mathrm{Mg}, \mathrm{Fe})_{2} \mathrm{Al}_{4} \mathrm{Si}_{9} \mathrm{O}_{34}(\mathrm{OH})_{4}\right]$

Jacobsite $\left[(\mathrm{Mn}, \mathrm{Fe} \cdot, \mathrm{Mg})\left(\mathrm{Fe}^{\cdots}, \mathrm{Mn}_{2} \mathrm{O}_{4}\right]\right.$

Limonite $\left[\mathrm{Fe}_{2} \mathrm{O}_{3} \cdot n \mathrm{H}_{2} \mathrm{O}\right]$

Magnetite $\left[\mathrm{Fe}_{3} \mathrm{O}_{4}\right]$

Malachite $\left[\mathrm{Cu}_{2} \mathrm{CO}_{3}(\mathrm{OH})_{2}\right]$

Mangancalcite $\left[(\mathrm{Mn}, \mathrm{Ca}) \mathrm{CO}_{3}\right]$

Manganophyllite $\left[\mathrm{K}_{2} \mathrm{Mn}_{5} \mathrm{Al}_{4} \mathrm{Si}_{5} \mathrm{O}_{10}(\mathrm{OH})_{4}\right]$

Manganphlogopite $\left[\mathrm{K}(\mathrm{Mg}, \mathrm{Mn})_{3} \mathrm{AlSi}_{3} \mathrm{O}_{10}(\mathrm{OH})_{2}\right]$

Manganosite [MnO]

Marcasite $\left[\mathrm{FeS}_{2}\right]$

Molybdenite $\left[\mathrm{MoS}_{2}\right]$

Muscovite $\left[\mathrm{KAl}_{3} \mathrm{Si}_{3} \mathrm{O}_{10}(\mathrm{OH})_{2}\right]$

Neotocite $\left[\mathrm{Mn}_{2} \mathrm{Fe}_{2} \mathrm{Si}_{4} \mathrm{O}_{18} \cdot 6 \mathrm{H}_{2} \mathrm{O}\right]$

Niccolite [NiAs]

Nickelpyrite $\left[(\mathrm{Fe}, \mathrm{Ni}) \mathrm{S}_{2}\right.$

Opal $\left[\mathrm{SiO}_{2} \cdot n \mathrm{H}_{2} \mathrm{O}\right]$

Orthoclase $\left[\mathrm{KAlSi}_{3} \mathrm{O}_{8}\right]$

Parsettensite $\left[\mathrm{Mn}_{10} \mathrm{Si}_{12} \mathrm{O}_{26}(\mathrm{OH})_{16}\right]$ ?

Penwithite $\left[\mathrm{MnSiO}_{3} \cdot 2 \mathrm{H}_{2} \mathrm{O}\right]$

Pentlandite $\left[(\mathrm{Fe}, \mathrm{Ni})_{9} \mathrm{~S}_{8}\right]$

Picrotephroite $\left[(\mathrm{Mn}, \mathrm{Mg})_{2} \mathrm{SiO}_{4}\right]$

Psilomelane [(Ba, Mn") $\left.\mathrm{Mn}^{\cdots}{ }_{4} \mathrm{O}_{8}(\mathrm{OH})_{2}\right]$

Pyrite $\left[\mathrm{FeS}_{2}\right]$

Pyrolusite $\left[\mathrm{MnO}_{2}\right]$

\begin{tabular}{|c|c|c|c|c|c|c|c|}
\hline \multicolumn{2}{|c|}{$\begin{array}{l}\text { Recrystallization products } \\
\text { due to thermal metamorphism }\end{array}$} & \multicolumn{2}{|c|}{$\begin{array}{l}\text { Pyrometasomatic products } \\
\text { (skarn) }\end{array}$} & $\begin{array}{l}\text { Pegmatitic or } \\
\text { pneumatolytic } \\
\text { products }\end{array}$ & \multicolumn{3}{|c|}{ Hydrothermal products } \\
\hline $\begin{array}{l}\text { In manganese } \\
\text { ores }\end{array}$ & In hornfels & $\begin{array}{l}\text { In manganese } \\
\text { ores }\end{array}$ & $\begin{array}{l}\text { In limestone } \\
\text { (skarn) }\end{array}$ & $\begin{array}{l}\text { In or near } \\
\text { manganese ore }\end{array}$ & $\begin{array}{l}\text { Replacement } \\
\text { mass }\end{array}$ & $\begin{array}{l}\text { Vein in man- } \\
\text { ganese deposit }\end{array}$ & $\begin{array}{l}\text { Vein in horn- } \\
\text { fels and chert }\end{array}$ \\
\hline
\end{tabular}

Supergen

Upper par

the mar

inese dep

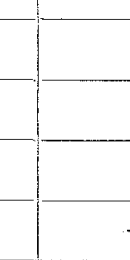

$+++$

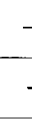

$+$

$++$

\begin{tabular}{c|c}
\hline- & - \\
\hline- & + \\
\hline- & + \\
\hline- & - \\
\hline- & -
\end{tabular}

$++$

$+$


The investigation was aided by a grant from the Scientific Research Fund of the Ministry of the Education.

\section{REFERENCES}

1) Doi, M.: Special publication of the Japan Mining Industry Assoc., Ser. No. 1, 34 (1949) (in Japanese).

2) Hamaji, T. and Y. Sakamaki: Mining Geol., 7 (4), 313 (1957) (in Japanese).

3) Kawai, K.: Jour. Geol. Soc. Jap., 40, 348 (1933) (in Japanese).

4) Kitahara, J.: Jour. Geol. Soc. Jap. 57, 338 (1951) (in Japanese).

5) - Jour. Geol. Soc. Jap. 58, 545 (1952) (in Japanese).

6) Lee, D. E.: Stanford Univ. Publ. Univ. Ser. Geol. Sci., 5, 1 (1955).

7) Miyamoto, H. and Y. Ishida: Bull. Geol. Surv. Japan, 8 (2), 13 (1957) (in Japanese).

8) Okumi, Y., T. Hamaji, J. Okano and Y. Sakamaki: Rept. Symposium for Atom. Energ., No. 2, B-63, 131 (1958) (in Japanese).

9) Omori, K. and S. Hasegawa: Jour. Jap. Assoc. Miner. Petrol. Econ. Geol., 41, 171 (1957) (in Japanese).

10) Sato, A., K. Fukuda and T. Wada: Mining Geol., 7 (23), 13; 7 (24), 98 (1957) (in Japanese).

11) Sugaki, A. and H. Abe: Unutilized iron resources of Japan in 1956 No. 3, 223 (1957) (in Japanese).

12) Takeuchi, T. and M. Nambu: Bull. Res. Inst. Mineral Dress. \& Metall. 9, (1953) (in Japanese).

13) Taliaferro, N. L.: Calif. Div. Mines Bull. 125, 277 (1943).

14) Tilley, C. E.: Geol. Mag., 86, 7 (1949).

15) Watanabe, T.: Jour. Geol. Soc. Japan, 58, 336 (1952) (in Japanese).

16) - Mining Geol., 7, 87 (1957) (in Japanese).

17) Yoshimura, T.: Jour. Geol. Soc. Japan, 44, 561 (1937) (in Japanese).

18) - Manganese deposits of Japan, (1952) (in Japanese).

Manuscript received July 1, 1959. 